\title{
Environmental Lead Exposure Accelerates Progressive Diabetic Nephropathy in Type II Diabetic Patients
}

\author{
Wen-Hung Huang, Ja-Liang Lin, Dan-Tzu Lin-Tan, Ching-Wei Hsu, \\ Kuan-Hsing Chen, and Tzung-Hai Yen \\ Department of Nephrology and Division of Clinical Toxicology, Chang Gung Memorial Hospital, Linkou Medical Center, \\ Chang Gung University and School of Medicine, 199 Tung-Hwa North Road, Taipei 10548, Taiwan
}

Correspondence should be addressed to Ja-Liang Lin; jllin99@hotmail.com

Received 12 November 2012; Accepted 24 January 2013

Academic Editor: Cheng-An J. Lin

Copyright ( $) 2013$ Wen-Hung Huang et al. This is an open access article distributed under the Creative Commons Attribution License, which permits unrestricted use, distribution, and reproduction in any medium, provided the original work is properly cited.

\begin{abstract}
Whether environmental lead exposure has a long-term effect on progressive diabetic nephropathy in type II diabetic patients remains unclear. A total of 107 type II diabetic patients with stage 3 diabetic nephropathy (estimated glomerular filtration rate (eGFR) range, $30-60 \mathrm{~mL} / \mathrm{min} / 1.73 \mathrm{~m}^{2}$ ) with normal body lead burden (BLB) ( $<600 \mu \mathrm{g} / 72 \mathrm{hr}$ in EDTA mobilization tests) and no history of exposure to lead were prospectively followed for 2 years. Patients were divided into high-normal BLB ( $>80 \mu \mathrm{g})$ and lownormal BLB $(<80 \mu \mathrm{g})$ groups. The primary outcome was a 2 -fold increase in the initial creatinine levels, long-term dialysis, or death. The secondary outcome was a change in eGFR over time. Forty-five patients reached the primary outcome within 2 years. Although there were no differences in baseline data and renal function, progressive nephropathy was slower in the low-normal BLB group than that in the high-normal BLB group. During the study period, we demonstrated that each $100 \mu \mathrm{g}$ increment in BLB and each $10 \mu \mathrm{g}$ increment in blood lead levels could decrease GFR by $2.2 \mathrm{~mL} / \mathrm{min} / 1.72 \mathrm{~m}^{2}$ and $3.0 \mathrm{~mL} / \mathrm{min} / 1.72 \mathrm{~m}^{2}(P=0.005)$, respectively, as estimated by generalized equations. Moreover, BLB was associated with increased risk of achieving primary outcome. Environmental exposure to lead may have a long-term effect on progressive diabetic nephropathy in type II diabetic patients.
\end{abstract}

\section{Introduction}

Over the past 25 years, the prevalence of type II diabetes in the USA has almost doubled, with 3- to 5-fold increases in developing countries [1]. Diabetes is now the major cause of end-stage renal disease and the primary diagnosis causing kidney disease in $20-40 \%$ of patients starting treatment for end-stage renal disease worldwide $[2,3]$. However, few studies have investigated the relationship between environmental exposure to lead and diabetic nephropathy.

Previous epidemiological studies [4-6] showed that blood lead levels (BLL) are related to renal function $[4,5]$ and exacerbated age-related decreases in renal function [6] in the general population, suggesting that environmental exposure to lead influences renal function in healthy individuals. Because BLL only indicates recent lead exposure $[4,7]$, body lead burden (BLB) is usually assessed by X-ray fluorescence to determine bone lead content and calcium disodium ethylenediaminetetraacetic acid (EDTA) mobilization tests [7]. A BLB greater than $600 \mu \mathrm{g}$, as determined by EDTA mobilization tests, is considered lead poisoning. Previous investigations that used EDTA mobilization tests to assess BLB in nondiabetic chronic kidney disease (CKD) patients with normal BLB [8-12] suggested that environmental lead exposure is associated with progressive CKD.

A 6-year study [13] indicated that bone lead content is related to progressive elevation of serum creatinine in persons with diabetes. However, these values were not adjusted for daily urinary protein excretion or daily protein intake. A short-term 1-year observational study [14] of type II diabetic patients with diabetic nephropathy suggested that environmental lead exposure might influence progressive diabetic nephropathy. However, the observation period was too short to demonstrate the long-term toxic effect of environmental 
lead exposure; therefore, the estimated glomerular filtration rate (eGFR) was calculated from the American Modification of Diet in Renal Disease (MDRD) formula for CKD patients [15] rather than the Chinese formula for type II diabetic patients [16]. Hence, the relationship between lowlevel environmental exposure to lead and progressive diabetic nephropathy remains unclear. This 2-year prospective study was performed to clarify the relationship in type II diabetic patients.

\section{Study Population and Methods}

2.1. Subjects. The Institutional Review Board Committee of Chang Gung Memorial Hospital approved the study protocol. Each patient provided written informed consent.

Patients aged from 30 to 83 years who had type II diabetes mellitus with nephropathy and who received followup care at Chang Gung Memorial for more than 1 year were eligible for inclusion in this study if they met all the following criteria [14]: abnormal serum creatinine $(>1.4 \mathrm{mg} / \mathrm{dL})$; stage $3 \mathrm{CKD}$ (eGFR between $30 \mathrm{~mL} / \mathrm{min} / 1.73 \mathrm{~m}^{2}$ and $60 \mathrm{~mL} / \mathrm{min} / 1.73 \mathrm{~m}^{2}$ ); diabetic retinopathy treated with or without laser therapy; daily urinary protein excretion of more than $0.5 \mathrm{~g} /$ day; no microhematuria in urine tests; normal-sized kidneys as determined by echograms; history of diabetes for more than 5 years; no known history of exposure to lead or other heavy metals; and a BLB of less than $600 \mu \mathrm{g}$ as measured by EDTA mobilization testing and 72-hour urine collection. Diabetic nephropathy diagnoses were also based on renal histological examination findings in cases where renal biopsies were performed.

The exclusion criteria were as follows: type I diabetes; renal insufficiency with a potentially reversible cause such as malignant hypertension, urinary tract infection, hypercalcemia, or drug-induced nephrotoxic effects; presence of other systemic diseases such as connective tissue diseases; use of drugs that might alter the course of renal disease such as nonsteroidal anti-inflammatory agents, steroids, immunosuppressive drugs, or Chinese herbal drugs; having joined a previous study [14]; drug allergies; and the absence of informed consent. The blood pressure of each patient was maintained at less than $140 / 90 \mathrm{~mm} \mathrm{Hg}$ with diuretics and angiotensin-converting-enzyme inhibitors (ACEI) or angiotensin II receptor antagonists (ARA), with or without calcium-blocking agents and/or vasodilators [17]. Calcium carbonate was employed to maintain patients' phosphate levels. No patients received vitamin D3 supplements because their parathyroid hormone was below $200 \mathrm{pg} / \mathrm{mL}$. Each patient received dietary consultation. A diabetic diet (35 Kcal $/ \mathrm{kg}$ of body weight per day) with normal-protein intake $(0.8-1.0 \mathrm{~g}$ of high biological value protein per kilogram of body weight per day) was recommended to each patient. A nutritionist reviewed the dietary intake of each patient every 3 to 6 months. A 24-hour urea excretion analysis was performed every 3 months to determine nitrogen balance and dietary compliance [18].

2.2. Measurements of Blood Lead Levels and Body Lead Burdens. BLL and BLB were measured as described previously
[7-12]. BLB was measured using EDTA mobilization tests as modified by Behringer et al. [19]. Urinary excretion measured 72 hours after the intravenous infusion of $1 \mathrm{~g}$ of calcium disodium EDTA (Abbott Laboratories, North Chicago, IL, USA) was used to measure BLB. Blood and urine lead levels were determined by electrothermal atomic-absorption spectrometry (SpectrAA-200Z; Varian, CA, USA) with Zeeman background correction and a L'vov platform. Both internal and external quality-control procedures were applied throughout this study and achieved consistently satisfactory results. A certified commercially prepared product (Seronorm Trace Elements, Sero AS, Billingstad, Norway) was utilized to monitor intrabatch accuracy and ensure interbatch standardization. The coefficient of variation for lead measurement was $<5.3 \%$. The detection limit was $0.01 \mu \mathrm{g} / \mathrm{dL}$. External quality control was maintained via participation in the governmental National Quality-Control Program. Low-normal BLB was defined as $<80 \mu \mathrm{g}$ and high-normal BLB was defined as $>80 \mu \mathrm{g}$ and $<600 \mu \mathrm{g}[9-12,14]$.

2.3. Study Protocol. Serum creatinine, glycosylated hemoglobin (HbAlc), daily urine protein excretion, daily protein intake, mean arterial pressure, cholesterol, and triglyceride levels were measured with an autoanalyzer system (model 736; Hitachi, Tokyo, Japan) at the beginning and end of the study and every 3 months during the 24-month clinical observation period. Blood pressure and body mass index were also measured at 3-month intervals. At the end of this period, we compared the changes in renal function between the 2 groups and assessed the relationship between BLB and the progressive decline of diabetic nephropathy. Renal function was assessed by creatinine clearance and eGFR (both in $\mathrm{mL} / \mathrm{min} / 1.73 \mathrm{~m}^{2}$ of body surface area). A modified eGFR equation for Chinese patients with type II diabetes was employed [16] (D-GFR) $\left(\mathrm{mL} / \mathrm{min} / 1.73 \mathrm{~m}^{2}\right)\left(R^{2}=0.95\right): 313 \times$ $(\text { age })^{-0.494}($ years $) \times[\mathrm{SCr}]^{-1.059}(\mathrm{mg} / \mathrm{dL}) \times[\mathrm{Alb}]^{+0.485}(\mathrm{~g} / \mathrm{dL})$ for men, and $783 \times(\text { age })^{-0.489}$ (years $) \times[S C r]^{-0.877}(\mathrm{mg} / \mathrm{dL})$ $\times[\mathrm{SUN}]^{-0.150}(\mathrm{mg} / \mathrm{dL})$ for women. A total of 85 patients completed the initial study period (Figure 1).

2.4. Outcome Measures. The primary endpoint was a 2-fold elevation in serum creatinine (measured twice, 1 month apart) from baseline values, need for long-term dialysis, or death during the 24-month observation period. The secondary endpoint was temporal changes in renal function during the study period.

2.5. Statistical Analysis. The differences in variables and renal function between the 2 groups were analyzed by the Chi-square test and Student's $t$-test. All $P$ values were twotailed, and all results are presented as means \pm SD. The Mann-Whitney $U$ test was employed for data not normally distributed. We performed a sensitivity analysis that assigned the mean eGFR value of the treatment group to controls lost to followup and assigned the mean eGFR value of the control group to treated patients lost to followup. Generalized estimating equations (GEE) with linear analysis were employed in longitudinal multivariate analyses using SAS statistical 


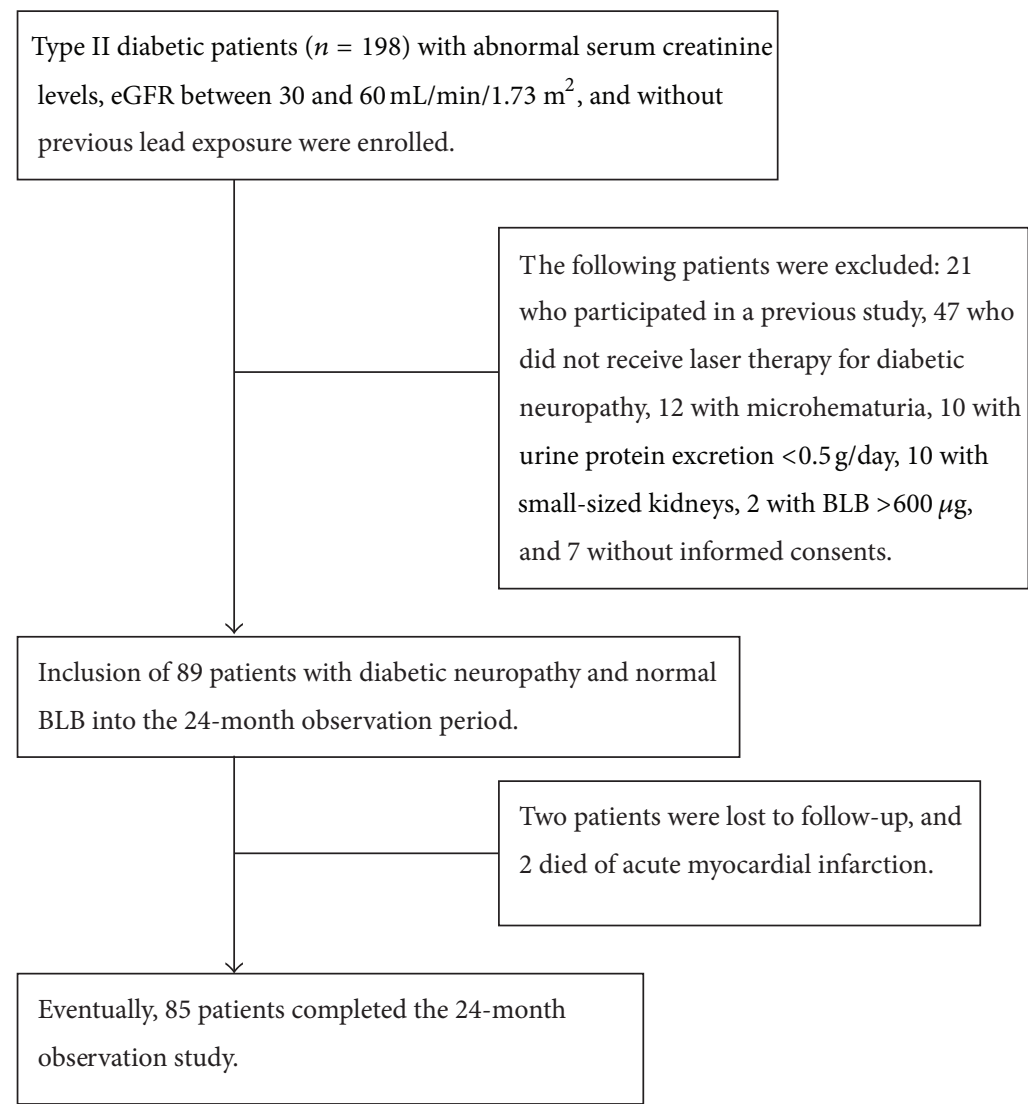

FIGURE 1: Flow chart showing the enrollment and status of patients.

software (version 6.12) to further assess the temporal changes in variables and associations with progressive renal function (eGFR) during the observation period. Moreover, multivariate Cox analyses were used to determine the significance of the baseline variables for predicting the primary endpoint during the study period. These models included all variables identified in the literature as related to the progression of diabetic nephropathy [12-16]. A value of $P<0.05$ was considered statistically significant. Data were analyzed using SPSS, version 18.0 for Windows 95 (SPSS Inc., Chicago, IL).

\section{Results}

3.1. Study Subjects. A total of 89 patients participated in the study and 85 completed the 24-month observation period (58 men and 31 women) (Figure 1). The following baseline data were obtained: patient mean age, $60.1 \pm 9.5$ years (range, 33-83); body-mass index (weight in kilograms divided by the square of height in meters), $24.9 \pm 3.3$ (range, 14.933.4 ); serum creatinine level, $1.9 \pm 0.3 \mathrm{mg} / \mathrm{dL}$ (range, $1.5-$ $2.8 \mathrm{mg} / \mathrm{dL})$; eGFR, $41.3 \pm 6.9 \mathrm{~mL} / \mathrm{min} / 1.73 \mathrm{~m}^{2}$ of body surface area (range, $30.3-59.9 \mathrm{~mL} / \mathrm{min} / 1.73 \mathrm{~m}^{2}$ of body surface area); daily protein excretion, $3.0 \pm 2.5 \mathrm{~g}$ (range, $0.5-12.2 \mathrm{~g}$ ); daily protein intake, $0.97 \pm 0.18 \mathrm{~g} / \mathrm{kg}$ (range, $0.58-1.63 \mathrm{~g} / \mathrm{kg}$ ); HbAlc, $8.3 \pm 1.9 \%$ (range, 5.7-14.7\%); BLL, $4.3 \pm 1.1 \mu \mathrm{g} / \mathrm{dL}$ (range, $0.8-10.4 \mu \mathrm{g} / \mathrm{dL}$ ); and BLB, $109.9 \pm 52.3 \mu \mathrm{g}$ (range, 14.4-316.8 $\mu \mathrm{g})$. Sixty-two patients $(70.0 \%)$ had hyperlipidemia. Eighty-four patients (95.5\%) had hypertension, and they were treated with ACEI or ARA. Fourteen patients (15.7\%) smoked. Seventy-six patients (85.4\%) had retinopathy, which was treated with laser therapy. Among all the study patients, 29 (32.6\%) had a history of cardiovascular diseases, including myocardial infarction, congestive heart failure, stroke, and diabetic foot. BLL was associated with BLB in all study patients $(r=0.274, P=0.009)$.

3.2. Longitudinal Followup for a 24-Month Period. Table 1 summarizes demographic data, baseline chronic disease condition, use of ACEI or ARA, daily urinary urea and protein levels, and body lead burden for participants in each group. No significant differences in these baseline values were noted between the 2 groups on initial assessment or during the observation period. Table 2 compares the progression of diabetic nephropathy between the high-normal BLB and lownormal BLB groups during the observation period. Creatinine clearance and eGFR were higher in the low-normal BLB group than in the high-normal BLB group during months 18 to 24 of the observation period. Similar results were obtained in the sensitivity test (Table 3).

3.3. Outcome Measures. Thirty-nine patients had a 2-fold elevation in serum creatinine from the baseline values during the 24-month observation period; 5 patients in the highnormal BLB group required hemodialysis; 1 patient with high-normal and 1 with low BLB died of acute myocardial 
TABLE 1: Baseline characteristics of patients with high-normal and low-normal body lead burden at the beginning of the observation period* .

\begin{tabular}{|c|c|c|c|}
\hline Variable & $\begin{array}{l}\text { Low-normal BLB group } \\
\qquad \begin{array}{c}(n=27) \\
(N=25)\end{array}\end{array}$ & $\begin{array}{l}\text { High-normal BLB group } \\
\qquad \begin{array}{c}(n=62) \\
(N=25)\end{array}\end{array}$ & $P$ value \\
\hline \multicolumn{4}{|l|}{ Age (yr) } \\
\hline Mean \pm SD & $60.7 \pm 8.3$ & $59.8 \pm 10.1$ & \multirow{2}{*}{0.698} \\
\hline Range & $46-79$ & $33-83$ & \\
\hline \multicolumn{4}{|l|}{ Sex (no. of patients) } \\
\hline Men/women & $17 / 10$ & $41 / 21$ & $0.812^{\dagger}$ \\
\hline Education yrs $>9$ yrs (no. of patients) & $13(39.4)$ & $30(40.5)$ & $0.911^{\dagger}$ \\
\hline \multicolumn{4}{|l|}{ Body-mass index $\left(\mathrm{kg} / \mathrm{m}^{2}\right)$} \\
\hline Mean \pm SD & $24.5 \pm 3.0$ & $25.1 \pm 3.7$ & \multirow{2}{*}{0.459} \\
\hline Range & $17.6-32.3$ & $14.9-33.4$ & \\
\hline Hyperlipidemia (no. of patients) $(\%)^{\wedge}$ & $16(60.6)$ & $46(68.9)$ & $0.210^{\dagger}$ \\
\hline Use of statin drugs (no. of patients) (\%) & $15(57.6)$ & $41(60.8)$ & $0.352^{\dagger}$ \\
\hline Hypertension (no. of patients) $(\%)^{\|}$ & $26(97.0)$ & $58(94.6)$ & $0.999^{\dagger}$ \\
\hline $\begin{array}{l}\text { Use of angiotensin-converting-enzyme inhibitors or } \\
\text { angiotensin-receptor antagonists (no. of patients) (\%) }\end{array}$ & $27(100.0)$ & $60(98.6)$ & $0.999^{\dagger}$ \\
\hline $\begin{array}{l}\text { Use of nondihydropyridine calcium channel blockers } \\
\text { (no. of patients) (\%) }\end{array}$ & $10(48.5)$ & $22(33.8)$ & $0.999^{\dagger}$ \\
\hline $\begin{array}{l}\text { Use of dihydropyridine calcium channel blockers (no. } \\
\text { of patients) (\%) }\end{array}$ & $9(27.3)$ & $24(40.5)$ & $0.812^{\dagger}$ \\
\hline Smoking (no. of patients) (\%) & $5(15.2)$ & $9(24.3)$ & $0.753^{\dagger}$ \\
\hline History of cardiovascular disease (no. of patients) (\%) & $8(36.4)$ & $21(29.7)$ & $0.808^{\dagger}$ \\
\hline Use of insulin at entry (no. of patients) (\%) & $6(18.2)$ & $16(24.3)$ & $0.795^{\dagger}$ \\
\hline \multicolumn{4}{|l|}{ HbAlc (\%) } \\
\hline Mean \pm SD & $8.2 \pm 2.1$ & $8.6 \pm 1.8$ & \multirow{2}{*}{0.367} \\
\hline Range & $5.8-14.0$ & $5.7-14.7$ & \\
\hline \multicolumn{4}{|l|}{ Mean arterial pressure $(\mathrm{mmHg})$} \\
\hline Mean \pm SD & $96.6 \pm 12.0$ & $98.6 \pm 11.9$ & \multirow{2}{*}{0.477} \\
\hline Range & $68.7-120$ & $75-126$ & \\
\hline \multicolumn{4}{|l|}{ Cholesterol (mg/dL) } \\
\hline Mean \pm SD & $211.0 \pm 38.2$ & $217.2 \pm 54.5$ & \multirow{2}{*}{0.596} \\
\hline Range & $124-278$ & $105-414$ & \\
\hline \multicolumn{4}{|l|}{ Triglycerides (mg/dL) } \\
\hline Mean \pm SD & $211.3 \pm 107.2$ & $206.2 \pm 187.6$ & \multirow{2}{*}{0.697} \\
\hline Range & $91-635$ & $56-1185$ & \\
\hline \multicolumn{4}{|l|}{ Serum creatinine $(\mathrm{mg} / \mathrm{dL})^{\ddagger}$} \\
\hline Mean \pm SD & $1.79 \pm 0.21$ & $1.88 \pm 0.30$ & \multirow{2}{*}{0.170} \\
\hline Range & $1.5-3.7$ & $1.5-3.8$ & \\
\hline \multicolumn{4}{|l|}{ Creatinine clearance rate $\left(\mathrm{mL} / \mathrm{min} / 1.73 \mathrm{~m}^{2}\right)$} \\
\hline Mean \pm SD & $44.9 \pm 10.8$ & $41.1 \pm 12.0$ & \multirow{2}{*}{0.123} \\
\hline Range & $29.2-61.4$ & $24.6-70.9$ & \\
\hline \multicolumn{4}{|l|}{ Glomerular filtration rate ${ }^{\odot}\left(\mathrm{mL} / \mathrm{min} / 1.73 \mathrm{~m}^{2}\right)$} \\
\hline Mean \pm SD & $42.4 \pm 6.2$ & $40.8 \pm 7.1$ & \multirow{2}{*}{0.380} \\
\hline Range & $31.9-58.3$ & $30.3-59.9$ & \\
\hline \multicolumn{4}{|l|}{ Blood lead $(\mu \mathrm{g} / \mathrm{dL})^{\#}$} \\
\hline Mean \pm SD & $3.8 \pm 3.0$ & $4.6 \pm 3.1$ & 0.278 \\
\hline Range & $1.6-10.4$ & $0.8-10.3$ & \\
\hline
\end{tabular}


TABLe 1: Continued.

\begin{tabular}{lcc}
\hline Variable & $\begin{array}{c}\text { Low-normal BLB group } \\
(n=27) \\
(N=25)\end{array}$ & $\begin{array}{c}\text { High-normal BLB group } \\
(n=62) \\
(N=25)\end{array}$ \\
\hline Body lead burden $(\mu \mathrm{g})^{\#}$ & & $132.4 \pm 46.1$ \\
$\quad$ Mean \pm SD & $58.1 \pm 16.7$ & $82.8-316.8$ \\
$\quad$ Range & $14.4-79.8$ & $3.2 \pm 2.4$ \\
Daily protein excretion $(\mathrm{g})$ & & $0.5-12.2$ \\
$\quad$ Mean \pm SD & $2.8 \pm 2.5$ & 0.364 \\
$\quad$ Range & $0.5-10.5$ & $0.96 \pm 0.18$ \\
Daily protein intake $(\mathrm{g} / \mathrm{kg})$ & & $0.53-1.68$ \\
$\quad$ Mean \pm SD & $0.99 \pm 0.16$ & 0.569 \\
$\quad$ Range & $0.60-1.55$ & 0.56 \\
\hline
\end{tabular}

*A high-normal body lead burden was defined as a lead value of at least $80 \mu \mathrm{g}(0.39 \mu \mathrm{mol})$ but less than $600 \mu \mathrm{g}(2.9 \mu \mathrm{mol})$ and a low-normal body lead burden as a lead value less than $80 \mu \mathrm{g}(0.39 \mu \mathrm{mol})$.

${ }^{\dagger} P$ values were calculated by Fisher's Chi-square test, except in the comparisons of age, body-mass index, serum creatinine, creatinine clearance, glomerular filtration rate, blood lead level, and body lead burden, which were calculated by Student's $t$-test.

${ }^{\ddagger}$ To convert values for serum creatinine to micromoles per liter, multiply by 88.4.

${ }^{\odot}$ Modified equation for glomerular filtration rate of Chinese diabetic patients.

${ }^{\#}$ To convert values for lead to micromoles per liter, multiply by 0.04286 .

${ }^{\wedge}$ Hyperlipidemia was defined as a serum cholesterol level above $240 \mathrm{mg}$ per deciliter ( $6.2 \mathrm{mmol}$ per liter) after diet control.

"Hypertension was defined by the presence of at least two blood-pressure measurements above 140/90 $\mathrm{mmHg}$ in patients.

Cardiovascular diseases included ischemic heart disease, congestive heart failure, stroke, and diabetic foot.

infarction; and 2 patients with high BLB were lost to followup. A total of $45(50.6 \%)$ patients reached the primary endpoint. Only $9(9 / 27,33.3 \%)$ patients had a body lead burden $<80 \mu \mathrm{g}$, and $36(36 / 62 ; 58.1 \%)$ of these subjects had body lead burdens $>80 \mu \mathrm{g}$ (Logrank tests, $P=0.023$ ) (Figure 2). In addition, GEE with linear analysis showed that BLB or BLL were significant variables for predicting the progression of eGFR, after adjusting for other variables (Tables 4 and 5). Each $1 \mu \mathrm{g}$ increase in BLB led to a decrease of $0.022 \mathrm{~mL} / \mathrm{min} / 1.73 \mathrm{~m}^{2}$ in eGFR $(P=0.009)$ and each $1 \mu \mathrm{g} / \mathrm{dL}$ increase in BLL led to a $0.298 \mathrm{~mL} / \mathrm{min} / 1.73 \mathrm{~m}^{2}$ decrease in eGFR $(P=0.010)$ during the 2-year study period. Moreover, multivariate Cox regression analysis demonstrated that BLB was a significant risk factor (hazard ratio $[\mathrm{HR}]=1.01,95 \%$ confidence interval [CI]: 1.01-1.02; $P<0.001)$ for achieving primary outcome in type II diabetic patients, even after adjustment for other factors (Table 6). Similarly, multivariate Cox regression analysis demonstrated that BLB $>80 \mu \mathrm{g}$ was a significant risk factor $(H R=2.79,95 \%$ CI: $1.25-6.25 ; P=0.012)$ for achieving primary outcome in these patients.

\section{Discussion}

The results of the present study indicate that BLB and BLL, even at low levels, are important risk factors for progressive diabetic nephropathy. These associations were strong, dose dependent, and consistent, even after comprehensive adjustments for other covariates. Our result is similar to those of previous reports showing that increased BLL is associated with a progressive decline in renal function in the general population $[4,5]$.

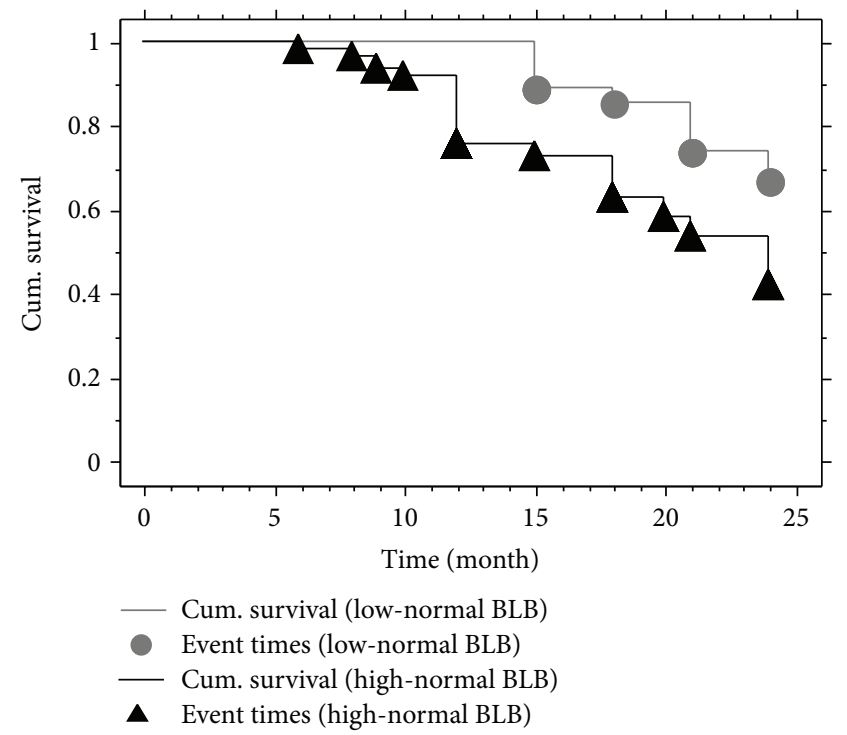

Figure 2: Kaplan-Meier analysis showing that patients with high body lead burden (BLB) $(>80$ and $<600 \mu \mathrm{g}$ ) had a higher likelihood $(58.1 \%, 36 / 62)$ of achieving the primary endpoint than those with low BLB $(<80 \mu \mathrm{g})(33.3 \%, 9 / 27$; Logrank tests, Chi-square $=5.17, P=$ 0.023 ) during the 24 -month followup period.

In comparison with our previous work [14], this study enrolled a different study cohort and showed several novel findings. First, patients with a high-normal BLB showed a higher incidence of progressive diabetic nephropathy than those with low-normal BLB, although the corresponding variables were not different between the 2 groups during the 2-year followup period. Moreover, similar results were 
TABLE 2: Means of renal function during the 24-month observation period $(n=89)$.

\begin{tabular}{|c|c|c|c|}
\hline $\begin{array}{l}\text { Renal function } \\
\left(\mathrm{mL} / \mathrm{min} / 1.73 \mathrm{~m}^{2}\right)\end{array}$ & $\begin{array}{l}\text { Low-normal BLB group } \\
\qquad(n=27)\end{array}$ & $\begin{array}{l}\text { High-normal BLB group } \\
\qquad(n=62)\end{array}$ & $P(95 \% \mathrm{CI})$ \\
\hline \multicolumn{4}{|l|}{ Month 0} \\
\hline Ccr & $44.9 \pm 10.8$ & $41.1 \pm 12.0$ & $0.123(-9.1-1.0)$ \\
\hline D-GFR & $42.4 \pm 6.2$ & $40.8 \pm 7.1$ & $0.300(-1.5-4.8)$ \\
\hline Month 6 & $(n=27)$ & $(n=62)$ & \\
\hline Ccr & $41.5 \pm 15.2$ & $33.1 \pm 13.0$ & $0.010(-14.6--2.1)$ \\
\hline D-GFR & $38.1 \pm 9.2$ & $32.9 \pm 8.3$ & $0.010(-9.1--1.3)$ \\
\hline Month 12 & $(n=27)$ & $(n=62)$ & \\
\hline Ccr & $41.0 \pm 19.2$ & $26.2 \pm 12.2$ & $<0.001(-21.6--8.1)$ \\
\hline D-GFR & $36.6 \pm 9.5$ & $27.2 \pm 8.9$ & $<0.001(-13.6--5.2)$ \\
\hline Month 18 & $(n=26)$ & $(n=59)$ & \\
\hline Ccr & $33.1 \pm 13.7$ & $24.5 \pm 10.8$ & $0.003(-14.1--3.0)$ \\
\hline D-GFR & $32.7 \pm 11.2$ & $23.7 \pm 8.0$ & $<0.001(-13.3--4.7)$ \\
\hline Month 24 & $(n=24)$ & $(n=55)$ & \\
\hline $\mathrm{Ccr}$ & $34.2 \pm 17.3$ & $19.8 \pm 9.8$ & $<0.001(-20.5--8.2)$ \\
\hline D-GFR & $31.4 \pm 11.2$ & $20.2 \pm 7.0$ & $<0.001(-15.3--7.1)$ \\
\hline \multicolumn{4}{|c|}{ Total decrease of renal function $\left(\mathrm{mL} / \mathrm{min} / 1.73 \mathrm{~m}^{2}\right)$ during the 2 -year observation period } \\
\hline $\mathrm{Ccr}$ & $12.1 \pm 15.5$ & $21.2 \pm 8.7$ & $0.002(3.7-14.5)^{\#}$ \\
\hline D-GFR & $11.3 \pm 11.7$ & $20.5 \pm 7.7$ & $0.001(4.8-13.7)^{\#}$ \\
\hline
\end{tabular}

Data were measured by the Student's $t$-test except ${ }^{*}$ data by Mann-Whitney method. $P<0.05$ means significant differences. Ccr: creatinine clearance; D-GFR: estimated GFR for Chinese patients with type II diabetes.

TABLE 3: Sensitivity analysis of renal function from month 18 to month 24 of the observation period $(n=89)$.

\begin{tabular}{|c|c|c|c|}
\hline $\begin{array}{l}\text { Renal function } \\
\left(\mathrm{mL} / \mathrm{min} / 1.73 \mathrm{~m}^{2}\right)\end{array}$ & $\begin{array}{l}\text { Low BLB group } \\
\quad(n=27)\end{array}$ & $\begin{array}{l}\text { High BLB group } \\
\qquad(n=62)\end{array}$ & $P(95 \% \mathrm{CI})$ \\
\hline \multicolumn{4}{|l|}{ Month 18} \\
\hline Ccr & $32.8 \pm 13.6$ & $24.9 \pm 10.7$ & $0.005(-13.2--2.5)$ \\
\hline D-GFR & $32.4 \pm 11.1$ & $24.2 \pm 8.1$ & $<0.001(-12.4--4.1)$ \\
\hline \multicolumn{4}{|l|}{ Month 24} \\
\hline Ccr & $32.6 \pm 16.1$ & $21.5 \pm 9.8$ & $<0.001(-16.9--5.4)$ \\
\hline D-GFR & $30.2 \pm 11.1$ & $21.5 \pm 7.5$ & $<0.001(-12.7--4.7)$ \\
\hline \multicolumn{4}{|c|}{ Total decrease of renal function $\left(\mathrm{mL} / \mathrm{min} / 1.73 \mathrm{~m}^{2}\right)$ during the 2-year observation period } \\
\hline Ccr & $12.2 \pm 14.6$ & $18.6 \pm 11.2$ & $0.010(0.7-12.0)^{\#}$ \\
\hline D-GFR & $12.3 \pm 11.5$ & $19.3 \pm 8.4$ & $0.006(2.7-11.3)^{\#}$ \\
\hline
\end{tabular}

Data were measured by the Student's $t$-test except ${ }^{*}$ data by Mann-Whitney method. $P<0.05$ means significant differences. Ccr: creatinine clearance; D-GFR: estimated GFR for Chinese patients with type II diabetes.

obtained in the sensitivity test. Second, each increment of $10 \mu \mathrm{g} / \mathrm{dL}$ of BLL was determined to potentially decrease GFR by $3.0 \mathrm{~mL} / \mathrm{min} / 1.73 \mathrm{~m}^{2}$ after adjustment for covariates. In addition to BLB, BLL is a strong predictor of progressive diabetic nephropathy and can be easily monitored in clinical practice. Importantly, there were no safe limits of lead indices in our study. Consistent with our results, previous studies of healthy populations indicated a high correlation between measured BLL and BLB [20, 21]. Therefore, one can assume that under conditions of constant environmental lead exposure, a higher BLL should correspond to a higher BLB. Third, the present study included a more homogenous population than our previous study [14]. Only patients with stage 3 CKD were included in the present study, whereas patients with stages 2, 3, and 4 CKD were included in our previous work [14]. Achieving primary outcome in patients with different stages of CKD is associated with confounding effects. Moreover, patients with stage $4 \mathrm{CKD}$ may have hyperparathyroidism, which can cause osteopathy; increase BLB, as measured by EDTA tests [22]; and result in selection bias in the classification of high-normal or lownormal BLB groups. Fourth, the eGFR was calculated from the Chinese-modified MDRD formula for CKD patients with type II diabetes rather than the formula used for American CKD patients. Lastly, because the present study used stricter definitions of the primary outcome (a 2-fold versus a 1.5-fold 
TABLE 4: Longitudinal multivariate analysis of body lead burden and other predictors of progressive change in the estimated glomerular filtration rate (D-GFR), using generalized estimating equations, during the 24-month longitudinal study period $(n=89)$.

\begin{tabular}{|c|c|c|}
\hline Variable & $\begin{array}{c}\text { Estimate } \\
\text { (interactive effect) }^{*}\end{array}$ & $P$ value \\
\hline Age (each increment of $1 \mathrm{yr}$ ) & -0.271 & $<0.001$ \\
\hline Gender (female versus male) & -3.575 & $<0.001$ \\
\hline Smoking (no versus yes) & -0.259 & 0.813 \\
\hline $\begin{array}{l}\text { Body-mass index }(\text { each } \\
\left.\text { increment of } 1 \mathrm{~kg} / \mathrm{m}^{2}\right)\end{array}$ & 0.020 & 0.852 \\
\hline $\begin{array}{l}\text { History of cardiovascular } \\
\text { diseases (no versus yes) }\end{array}$ & -0.375 & 0.686 \\
\hline $\begin{array}{l}\text { MAP }(\mathrm{mmHg}) \text { (each increment } \\
\text { of } 1 \mathrm{mmHg})\end{array}$ & -0.054 & 0.033 \\
\hline $\begin{array}{l}\text { Cholesterol }(\mathrm{mg} / \mathrm{dL})(\text { each } \\
\text { increment of } 1 \mathrm{mg} / \mathrm{dL})\end{array}$ & -0.002 & 0.811 \\
\hline $\begin{array}{l}\text { Triglycerides }(\mathrm{mg} / \mathrm{dL})(\text { each } \\
\text { increment of } 1 \mathrm{mg} / \mathrm{dL})\end{array}$ & -0.004 & 0.075 \\
\hline $\begin{array}{l}\text { HbAlc }(\%) \text { (each increment of } \\
1 \%)\end{array}$ & 0.013 & 0.793 \\
\hline $\begin{array}{l}\text { Serum creatinine }(\mathrm{mg} / \mathrm{dL}) \text { (each } \\
\text { increment of } 1 \mathrm{mg} / \mathrm{dL})\end{array}$ & -6.997 & $<0.001$ \\
\hline $\begin{array}{l}\text { Body lead burden }(\mu \mathrm{g}) \text { (each } \\
\text { increment of } 1 \mu \mathrm{g})\end{array}$ & -0.022 & 0.009 \\
\hline $\begin{array}{l}\text { Daily protein intake }(\mathrm{g} / \mathrm{kg}) \text { (each } \\
\text { increment of } 1 \mathrm{~g} / \mathrm{kg})\end{array}$ & 1.287 & 0.460 \\
\hline $\begin{array}{l}\text { Daily protein excretion (g) (each } \\
\text { increment of } 1 \mathrm{~g} \text { ) }\end{array}$ & -0.417 & 0.035 \\
\hline
\end{tabular}

The interactive effect of variables was calculated by a generalized estimating equation. Negative values for the interactive effect indicate a decline in the glomerular filtration rate, and positive values indicate an increase. Cardiovascular diseases included ischemic heart disease, congestive heart failure, stroke, and diabetic foot. MAP: mean arterial pressure.

increase in serum creatinine level from that of the baseline) and a longer followup period (24 months versus 12 months) than previous studies $[13,14]$, a more definitive conclusion regarding the long-term effect of environmental exposure to lead on progressive diabetic nephropathy can be drawn.

The mean BLL of our patients was only $4.3 \mu \mathrm{g} / \mathrm{dL}$, which is lower than observed in our previous study [14] and slightly higher than that reported by nationwide surveys in Taiwan $(3.0 \mu \mathrm{g} / \mathrm{dL})$ [23], Europe $(2.57 \mu \mathrm{g} / \mathrm{dL})$ [24], and the USA $(3.5 \mu \mathrm{g} / \mathrm{dL})$ [25]. This difference could be the result of the older age (mean, 60.1 years old) of our study patients. The mean BLB of our patients was only $109.9 \mu \mathrm{g}$, which is much lower than subtle lead poisoning (>600 $\mu \mathrm{g})$ levels [7]. Although there were no differences in baseline data, KaplanMeier analysis showed that patients with high-normal BLB were more likely (58.1\%) to achieve the primary outcome than those $(33.3 \%)$ with low-normal BLB during the 24-month followup. Multivariate Cox analysis indicated each 100- $\mu \mathrm{g}$ increase of BLB could lead to a $100 \%$ increase in the risk of achieving primary outcome. Consistent with this result, EDTA chelation therapy has shown benefits in retarding progressive diabetic nephropathy in type II diabetic patients with
TABLE 5: Longitudinal multivariate analysis of blood lead level and other predictors of progressive change in the estimated glomerular filtration rate (D-GFR), using generalized estimating equations, during the 24-month longitudinal study period $(n=89)$.

\begin{tabular}{|c|c|c|}
\hline Variable & $\begin{array}{c}\text { Estimate } \\
\text { (interactive effect) }^{*}\end{array}$ & $P$ value \\
\hline Age (each increment of $1 \mathrm{yr}$ ) & -0.268 & $<0.001$ \\
\hline Gender (female versus male) & -3.261 & $<0.001$ \\
\hline Smoking (no versus yes) & -0.631 & 0.604 \\
\hline $\begin{array}{l}\text { Body-mass index (each } \\
\text { increment of } 1 \mathrm{~kg} / \mathrm{m}^{2} \text { ) }\end{array}$ & -0.018 & 0.861 \\
\hline $\begin{array}{l}\text { Previous cardiovascular diseases } \\
\text { (no versus yes) }\end{array}$ & -0.220 & 0.818 \\
\hline $\begin{array}{l}\text { MAP }(\mathrm{mmHg}) \text { (each increment } \\
\text { of } 1 \mathrm{mmHg})\end{array}$ & -0.057 & 0.025 \\
\hline $\begin{array}{l}\text { Cholesterol }(\mathrm{mg} / \mathrm{dL})(\text { each } \\
\text { increment of } 1 \mathrm{mg} / \mathrm{dL})\end{array}$ & -0.006 & 0.406 \\
\hline $\begin{array}{l}\text { Triglycerides }(\mathrm{mg} / \mathrm{dL})(\text { each } \\
\text { increment of } 1 \mathrm{mg} / \mathrm{dL})\end{array}$ & -0.005 & 0.024 \\
\hline $\begin{array}{l}\text { HbAlc }(\%) \text { (each increment of } \\
1 \%)\end{array}$ & -0.002 & 0.976 \\
\hline $\begin{array}{l}\text { Serum creatinine }(\mathrm{mg} / \mathrm{dL}) \text { (each } \\
\text { increment of } 1 \mathrm{mg} / \mathrm{dL})\end{array}$ & -7.550 & $<0.001$ \\
\hline $\begin{array}{l}\text { Blood lead level }(\mu \mathrm{g} / \mathrm{dL}) \text { (each } \\
\text { increment of } 1 \mu \mathrm{g} / \mathrm{dL})\end{array}$ & -0.298 & 0.010 \\
\hline $\begin{array}{l}\text { Daily protein intake }(\mathrm{g} / \mathrm{kg}) \text { (each } \\
\text { increment of } 1 \mathrm{~g} / \mathrm{kg} \text { ) }\end{array}$ & 1.143 & 0.539 \\
\hline $\begin{array}{l}\text { Daily protein excretion }(\mathrm{g}) \text { (each } \\
\text { increment of } 1 \mathrm{~g} \text { ) }\end{array}$ & -0.400 & 0.045 \\
\hline
\end{tabular}

The interactive effect of variables was calculated by a generalized estimating equation. Negative values for the interactive effect indicate a decline in the glomerular filtration rate, and positive values indicate an increase. Cardiovascular diseases included ischemic heart disease, congestive heart failure, stroke, and diabetic foot. MAP: mean arterial pressure.

high-normal BLB $[14,26]$. Hence, environmental exposure to lead may accelerate progressive diabetic nephropathy in these patients, and it is reasonable to suggest chelation therapy for patients with high-normal BLB, who accounted for $70 \%$ $(62 / 89)$ of the current study patients.

The mechanism underlying the effect of environmental exposure to low-levels of lead on accelerating the development of progressive diabetic nephropathy remains unclear. Low-level lead exposure in a rat CKD model was found to hasten progressive CKD by accelerating microvascular and tubulointerstitial injury [27]. Studies performed on animals $[28,29]$ have shown that chronic exposure to low-dose lead results in the generation of reactive oxygen species, reduces nitric oxide availability and the expression of angiotensin II, and increases blood pressure [29]. It also promotes hydroxyl radical generation and lipid peroxidation [30], enhances vascular reactivity to sympathetic stimulation, and decreases DNA repair capacity, which might be relevant for rapidly dividing cells in the inflamed arterial wall [31]. Moreover, chronic exposure to low-level lead-induced oxidative stress and reduced nitric oxide availability were successfully treated with a lead chelating agent or antioxidants in rats $[29,32]$. 
TABLE 6: Cox regression analysis of the overall risk of the primary outcome of progressive renal insufficiency, according to baseline prognostic factors $(N=89)$.

\begin{tabular}{|c|c|c|}
\hline Variable & $\begin{array}{l}\text { Hazard ratio } \\
(95 \% \mathrm{CI})^{*}\end{array}$ & $P$ value \\
\hline Age (each increment of $1 \mathrm{yr}$ ) & $0.98(0.94-1.02)$ & 0.337 \\
\hline Female sex & $1.83(0.87-3.83)$ & 0.111 \\
\hline Smoking (no versus yes) & $0.75(0.26-2.12)$ & 0.582 \\
\hline $\begin{array}{l}\text { Baseline body-mass index (each } \\
\text { increment of } 1 \mathrm{~kg} / \mathrm{m}^{2} \text { ) }\end{array}$ & $0.90(0.81-0.99)$ & 0.023 \\
\hline $\begin{array}{l}\text { Previous cardiovascular diseases } \\
\text { (no versus yes) }\end{array}$ & $0.55(0.24-1.29)$ & 0.170 \\
\hline $\begin{array}{l}\text { MAP (mmHg) (each increment of } \\
1 \mathrm{mmHg})\end{array}$ & $1.03(1.00-1.06)$ & 0.088 \\
\hline $\begin{array}{l}\text { Cholesterol }(\mathrm{mg} / \mathrm{dL})(\text { each } \\
\text { increment of } 1 \mathrm{mg} / \mathrm{dL})\end{array}$ & $1.00(0.99-1.01)$ & 0.822 \\
\hline $\begin{array}{l}\text { Triglycerides }(\mathrm{mg} / \mathrm{dL}) \text { (each } \\
\text { increment of } 1 \mathrm{mg} / \mathrm{dL})\end{array}$ & $1.00(1.00-1.00)$ & 0.937 \\
\hline HbAlc (\%) (each increment of $1 \%)$ & $0.98(0.83-1.16)$ & 0.806 \\
\hline $\begin{array}{l}\text { Baseline serum creatinine (each } \\
\text { increment of } 1 \mathrm{mg} / \mathrm{dL} \text { ) }\end{array}$ & $0.29(0.06-1.29)$ & 0.104 \\
\hline $\begin{array}{l}\text { Body lead burden (each increment } \\
\text { of } 1 \mu \mathrm{g} \text { ) }\end{array}$ & $1.01(1.01-1.02)$ & $<0.001$ \\
\hline $\begin{array}{l}\text { Baseline daily protein intake (each } \\
\text { increment of } 1 \mathrm{~g} / \mathrm{kg} \text { ) }\end{array}$ & $0.41(1.06-1.44)$ & 0.462 \\
\hline $\begin{array}{l}\text { Baseline daily protein excretion } \\
\text { (each increment of } 1 \mathrm{~g} \text { ) }\end{array}$ & $1.24(1.12-1.42)$ & 0.008 \\
\hline
\end{tabular}

Cardiovascular diseases included ischemic heart disease, congestive heart failure, stroke, and diabetic foot. MAP: mean arterial pressure.

These findings support that chronic exposure to low-levels of lead may have a negative effect on diabetic nephropathy. Several recent nationwide epidemiological studies also indicated that environmental exposure to lead, even at low levels, is associated with CKD in the general population [33, 34]. Moreover, higher BLL in the range below $10 \mu \mathrm{g} / \mathrm{dL}$ was shown to be related to lower cystatin-estimated GFR [35] in adolescents. These previous studies support the current study results. However, much remains to be explored regarding the mechanisms of lead-induced progressive diabetic nephropathy.

The use of eGFR to assess altered renal function is one of the limitations of the present study. However, a study on eGFR in Chinese patients with type II diabetes conducted by Barbosa et al. [36] demonstrated a strong correlation between eGFR and isotopic GFR $\left(r^{2}=0.95\right)$ in the Chinese population. Another limitation of this study was that BLB was not assessed using X-ray fluorescence methods. However, there are several important limitations associated with X-ray fluorescence-based methods [36], such as lack of precision, nonhomogenous lead distribution in cortical bone, and a low turnover rate with low biological activity of lead in cortical bone. However, lead that can be chelated by EDTA predominantly reflects lead concentrations in the blood and soft tissues. Because the kidneys are included among soft tissues, EDTA mobilization may reflect the lead content of the kidney [37], which may influence progressive CKD.

\section{Conclusion}

The results of this prospective study indicate that environmental exposure to lead may accelerate progressive diabetic nephropathy in type II diabetic patients despite the control of treatable factors during long-term followup. These results suggest that avoiding exposure to any sources of lead in the environment and chelation therapy are important in patients with BLB $>80 \mu \mathrm{g}$. The findings of the current study are important because diabetic nephropathy is the major cause of end-stage renal disease in the world.

\section{Conflict of Interests}

All authors report that there is no conflict of interests.

\section{Acknowledgment}

The authors acknowledge the support of the National Science Council, Taiwan, under Contract no. NSC: 93-2314-B-182A079.

\section{References}

[1] K. H. Yoon, J. H. Lee, J. W. Kim et al., "Epidemic obesity and type 2 diabetes in Asia," The Lancet, vol. 368, no. 9548, pp. 1681-1688, 2006.

[2] National Institutes of Health, National Institute of Diabetes and Digestive and Kidney Diseases, International Comparisons, in 2007 Annual Data Report: Atlas of Chronic Kidney Disease and End-Stage Renal Disease in the United States, National Institutes of Health, National Institute of Diabetes and Digestive and Kidney Diseases, Bethesda, Md, USA, 2007.

[3] US Renal Data System, USRDS 1999 Annual Data Report, National Institutes of Health, National Institute of Diabetes and Digestive and Kidney Diseases, Bethesda, Md, USA, 1999.

[4] J. A. Staessen, R. R. Lauwerys, J. P. Buchet et al., "Impairment of renal function with increasing blood lead concentrations in the general population," New England Journal of Medicine, vol. 327, no. 3, pp. 151-156, 1992.

[5] M. Payton, H. Hu, D. Sparrow, and S. T. Weiss, "Low-level lead exposure and renal function in the normative aging study," American Journal of Epidemiology, vol. 140, no. 9, pp. 821-829, 1994.

[6] R. Kim, A. Rotnitzky, D. Sparrow, S. T. Weiss, C. Wager, and H. $\mathrm{Hu}$, "A longitudinal study of low-level lead exposure and impairment of renal function: the normative aging study," Journal of the American Medical Association, vol. 275, no. 15, pp. 1177-1181, 1996.

[7] J. L. Lin, K. H. Yeh, H. C. Tseng et al., "Urinary N-acetylglucosaminidase excretion and environmental lead exposure," American Journal of Nephrology, vol. 13, no. 6, pp. 442-447, 1993.

[8] D. T. Lin-Tan, J. L. Lin, T. H. Yen, K. H. Chen, and Y. L. Huang, "Long-term outcome of repeated lead chelation therapy in progressive non-diabetic chronic kidney diseases," Nephrology Dialysis Transplantation, vol. 22, no. 10, pp. 2924-2931, 2007.

[9] J. L. Lin, D. T. Tan, K. H. Hsu, and C. C. Yu, "Environmental lead exposure and progressive renal insufficiency," Archives of Internal Medicine, vol. 161, no. 2, pp. 264-271, 2001.

[10] C. C. Yu, J. L. Lin, and D. T. Lin-Tan, "Environmental exposure to lead and progression of chronic renal disease: a four-year 
prospective longitudinal study," Journal of the American Society of Nephrology, vol. 15, no. 4, pp. 1016-1022, 2004.

[11] J. L. Lin, D. T. Tan, H. H. Ho, and C. C. Yu, "Environmental lead exposure and urate excretion in the general population," American Journal of Medicine, vol. 113, no. 7, pp. 563-568, 2002.

[12] J. L. Lin, D. T. Lin-Tan, K. H. Hsu, and C. C. Yu, "Environmental lead exposure and progression of chronic renal diseases in patients without diabetes," New England Journal of Medicine, vol. 348, no. 4, pp. 277-286, 2003.

[13] S. W. Tsaih, S. Korrick, J. Schwartz et al., "Lead, diabetes, hypertension, and renal function: the normative aging study, Environmental Health Perspectives, vol. 112, no. 11, pp. 1178-1182, 2004.

[14] J. L. Lin, D. T. Lin-Tan, C. C. Yu, Y. J. Li, Y. Y. Huang, and K. L. Li, "Environmental exposure to lead and progressive diabetic nephropathy in patients with type II diabetes," Kidney International, vol. 69, no. 11, pp. 2049-2056, 2006.

[15] A. S. Levey, J. P. Bosch, J. B. Lewis, T. Greene, N. Rogers, and D. Roth, "A more accurate method to estimate glomerular filtration rate from serum creatinine: a new prediction equation," Annals of Internal Medicine, vol. 130, no. 6, pp. 461-470, 1999.

[16] T. K. Leung, A. O. Y. Luk, W. Y. So, M. K. W. Lo, and J. C. N. Chan, "Development and validation of equations estimating glomerular filtration rates in Chinese patients with type 2 diabetes," Kidney International, vol. 77, no. 8, pp. 729-735, 2010.

[17] B. O. Burney, R. G. Kalaitzidis, and G. L. Bakris, "Novel therapies of diabetic nephropathy," Current Opinion in Nephrology and Hypertension, vol. 18, no. 2, pp. 107-111, 2009.

[18] B. Isaksson, "Urinary nitrogen output as a validity test in dietary surveys," American Journal of Clinical Nutrition, vol. 33, no. 1, pp. 4-5, 1980.

[19] D. Behringer, P. Craswell, and C. Mohl, "Urinary lead excretion in uremic patients," Nephron, vol. 42, no. 4, pp. 323-329, 1986.

[20] V. Batuman, "Lead nephropathy, gout, and hypertension," American Journal of the Medical Sciences, vol. 305, no. 4, pp. 241247, 1993.

[21] M. Loghman-Adham, "Renal effects of environmental and occupational lead exposure," Environmental Health Perspectives, vol. 105, no. 9, pp. 928-938, 1997.

[22] M. Kessler, P. Y. Durand, T. C. Huu et al., "Mobilization of lead from bone in end-stage renal failure patients with secondary hyperparathyroidism," Nephrology Dialysis Transplantation, vol. 14, no. 11, pp. 2731-2733, 1999.

[23] W. T. Wu, P. J. Tsai, Y. H. Yang, C. Y. Yang, K. F. Cheng, and T. N. Wu, "Health impacts associated with the implementation of a national petrol-lead phase-out program (PLPOP): evidence from Taiwan between 1981 and 2007," Science of the Total Environment, vol. 409, no. 5, pp. 863-867, 2011.

[24] G. Falq, A. Zeghnoun, M. Pascal et al., "Blood lead levels in the adult population living in France the French Nutrition and Health Survey (ENNS 2006-2007)," Environment International, vol. 37, no. 3, pp. 565-571, 2011.

[25] D. Martin, T. A. Glass, K. Bandeen-Roche, A. C. Todd, W. Shi, and B. S. Schwartz, "Association of blood lead and tibia lead with blood pressure and hypertension in a community sample of older adults," American Journal of Epidemiology, vol. 163, no. 5, pp. 467-478, 2006.

[26] K.-H. Chen, J.-L. Lin, D.-T. Lin-Tan et al., "Effect of chelation therapy on progressive diabetic nephropathy in patients with type 2 diabetes and high-normal body lead burdens," American Journal of Kidney Diseases, vol. 60, no. 4, pp. 530-538, 2012.
[27] C. Roncal, W. Mu, S. Reungjui et al., "Lead, at low levels, accelerates arteriolopathy and tubulointerstitial injury in chronic kidney disease," American Journal of Physiology, vol. 293, no. 4, pp. F1391-F1396, 2007.

[28] B. Rodríguez-Iturbe, R. K. Sindhu, Y. Quiroz, and N. D. Vaziri, "Chronic exposure to low doses of lead results in renal infiltration of immune cells, NF- $\kappa$ B activation, and overexpression of tubulointerstitial angiotensin II," Antioxidants and Redox Signaling, vol. 7, no. 9-10, pp. 1269-1274, 2005.

[29] N. D. Vaziri, "Mechanisms of lead-induced hypertension and cardiovascular disease," American Journal of Physiology, vol. 295, no. 2, pp. H454-H465, 2008.

[30] Y. Ding, H. C. Gonick, and N. D. Vaziri, "Lead promotes hydroxyl radical generation and lipid peroxidation in cultured aortic endothelial cells," American Journal of Hypertension, vol. 13, no. 5, pp. 552-555, 2000.

[31] T. S. Nawrot and J. A. Staessen, "Low-level environmental exposure to lead unmasked as silent killer," Circulation, vol. 114, no. 13, pp. 1347-1349, 2006.

[32] N. Aykin-Burns, E. A. Franklin, and N. Ercal, "Effects of Nacetylcysteine on lead-exposed PC-12 cells," Archives of Environmental Contamination and Toxicology, vol. 49, no. 1, pp. 119-123, 2005.

[33] P. Muntner, J. He, S. Vupputuri, J. Coresh, and V. Batuman, "Blood lead and chronic kidney disease in the general United States population: results from NHANES III," Kidney International, vol. 63, no. 3, pp. 1044-1050, 2003.

[34] A. Navas-Acien, M. Tellez-Plaza, E. Guallar et al., "Blood cadmium and lead and chronic kidney disease in US sdults: a joint analysis," American Journal of Epidemiology, vol. 170, no. 9, pp. 1156-1164, 2009.

[35] J. J. Fadrowski, A. Navas-Acien, M. Tellez-Plaza, E. Guallar, V. M. Weaver, and S. L. Furth, "Blood lead level and kidney function in US adolescents: the third national health and nutrition examination survey," Archives of Internal Medicine, vol. 170, no. 1, pp. 75-82, 2010.

[36] F. Barbosa, J. E. Tanus-Santos, R. F. Gerlach, and P. J. Parsons, "A critical review of biomarkers used for monitoring human exposure to lead: advantages, limitations, and future needs," Environmental Health Perspectives, vol. 113, no. 12, pp. 16691674, 2005

[37] A. I. Sánchez-Fructuoso, M. Cano, M. Arroyo, C. Fernández, D. Prats, and A. Barrientos, "Lead mobilization during calcium disodium ethylenediaminetetraacetate chelation therapy in treatment of chronic lead poisoning," American Journal of Kidney Diseases, vol. 40, no. 1, pp. 51-58, 2002. 

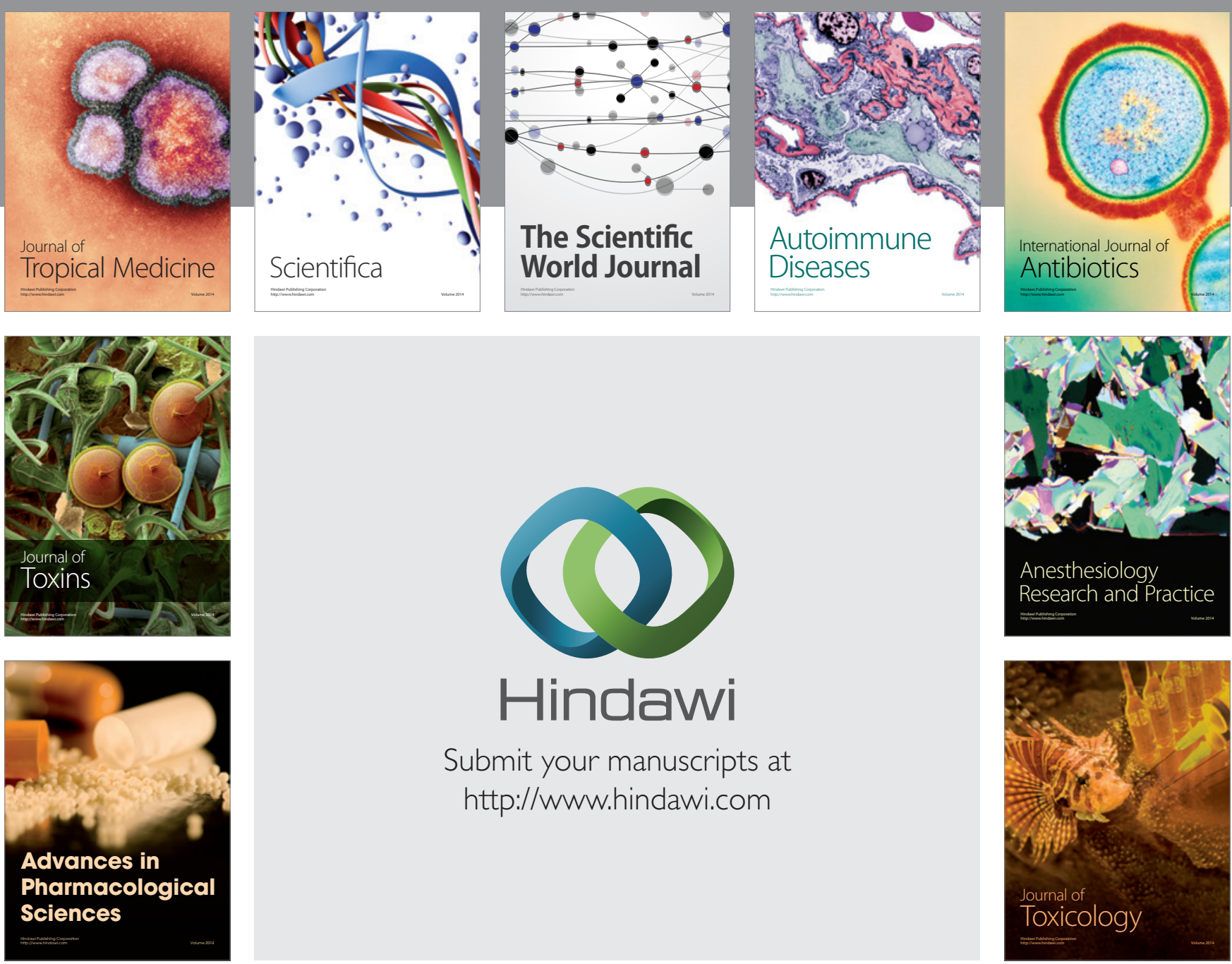

\section{Hindawi}

Submit your manuscripts at

http://www.hindawi.com
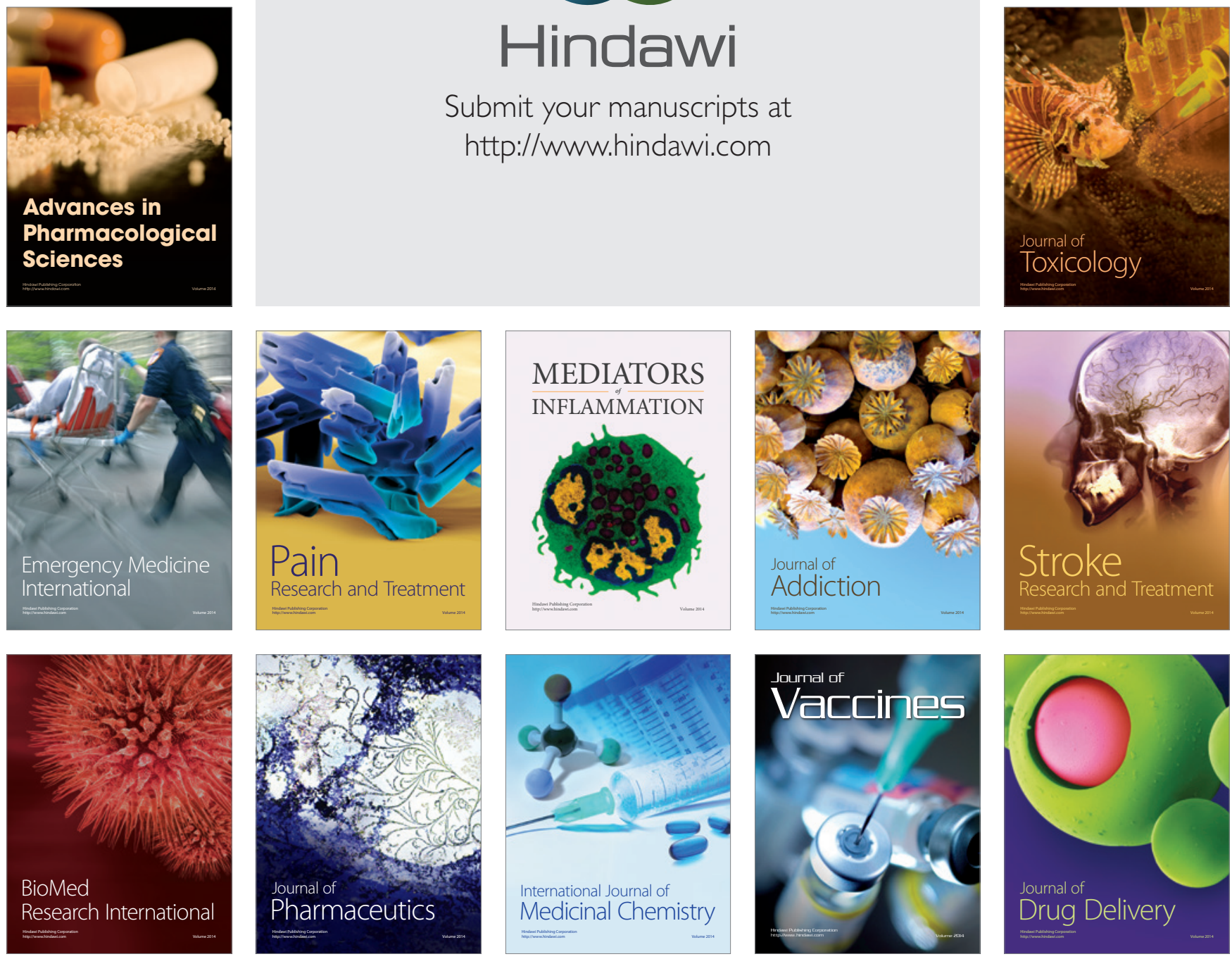